\title{
Observations on the Flagellar Appendages on the Plasma Membrane of Degenerating Spermatids of Homona magnanima Diakonoff. (Lepidoptera: Tortricidae)
}

\author{
Saleem A. Qureshi \\ Department of Anatomy, School of Medicine, Chiba University \\ Chiba 280, Japan
}

Received May 14, 1982

Several investigators have studied Lepidopteran testicular sperms at the ultrastructural level. André described the axial filament and mitochondrial derivatives of Macroglossum and Pieris respectively $(1959,1961)$. Some details of Ephestia sperm were shown by Smith (1968). Yasuzumi and Ôra (1964 a, 1964 b, 1965 a, 1965 b) described two novel bodies, which they called the clear band and tubular structure in the spermatids of Bombyx. These authors have reported a mantle bearing a number of laminated appendages of unknown function on the cell surface in flagellar region of spermatids on the side adjoining the mitochondrial rod. These radially arranged 'spokes' of laminated construction make the reproductive system of Lepidoptera quite complex as compared to that of most other insects. The phenomenon of degeneration of germ cells is also known to be widely occurring at all stages of spermatogenesis in Lepidopteran species (Roosen-Runge 1977). Knaben (1931) described abnormal spermatids occurring simultaneously in the testicular cysts of Tischeria angusticolella (Dup). Meves (1903) described two types of spermatocytes in Lepidoptera according to their sizes, the larger ones producing normal spermatids and sperm, and the smaller ones which after abnormal maturation division produced abnormal (apyrene) sperms. In the present study degenerating spermatids in certain testicular cysts of Homona magnanima have been studied with particular reference to the flagellar appendages which appeared to far exceed the number of such appendages so far reported on the flagellar region of sperms of butterflies and moths.

\section{Material and methods}

Pupae of the tea-tortrix moth were obtained from the National Institute of Agricultural Sciences, Ibaragi, Japan. The adult male moths, immediately after emergence, were dissected under a stereomicroscope in $2.5 \%$ glutaraldehyde at $\mathrm{pH} 7.4$ with Millonig's buffer. The testes were carefully dissected from the abdomen and fixed again in the fixative for several hours. After washing with buffer, the testes were post-fixed in cold $1 \%$ osmium tetraoxide buffered at $\mathrm{pH} 7.2$ for two to three hours. After rapid dehydration in a series of cold ethanols, they were embedded in Epon 812 through propylene oxide. Silver and gold sections were obtained by using the Servall (M. T. 1) microtome with a glass knife. The sections were stained with

1 Present address: Division of Applied Biology, PCSIR Laboratories, Karachi, Pakistan. 

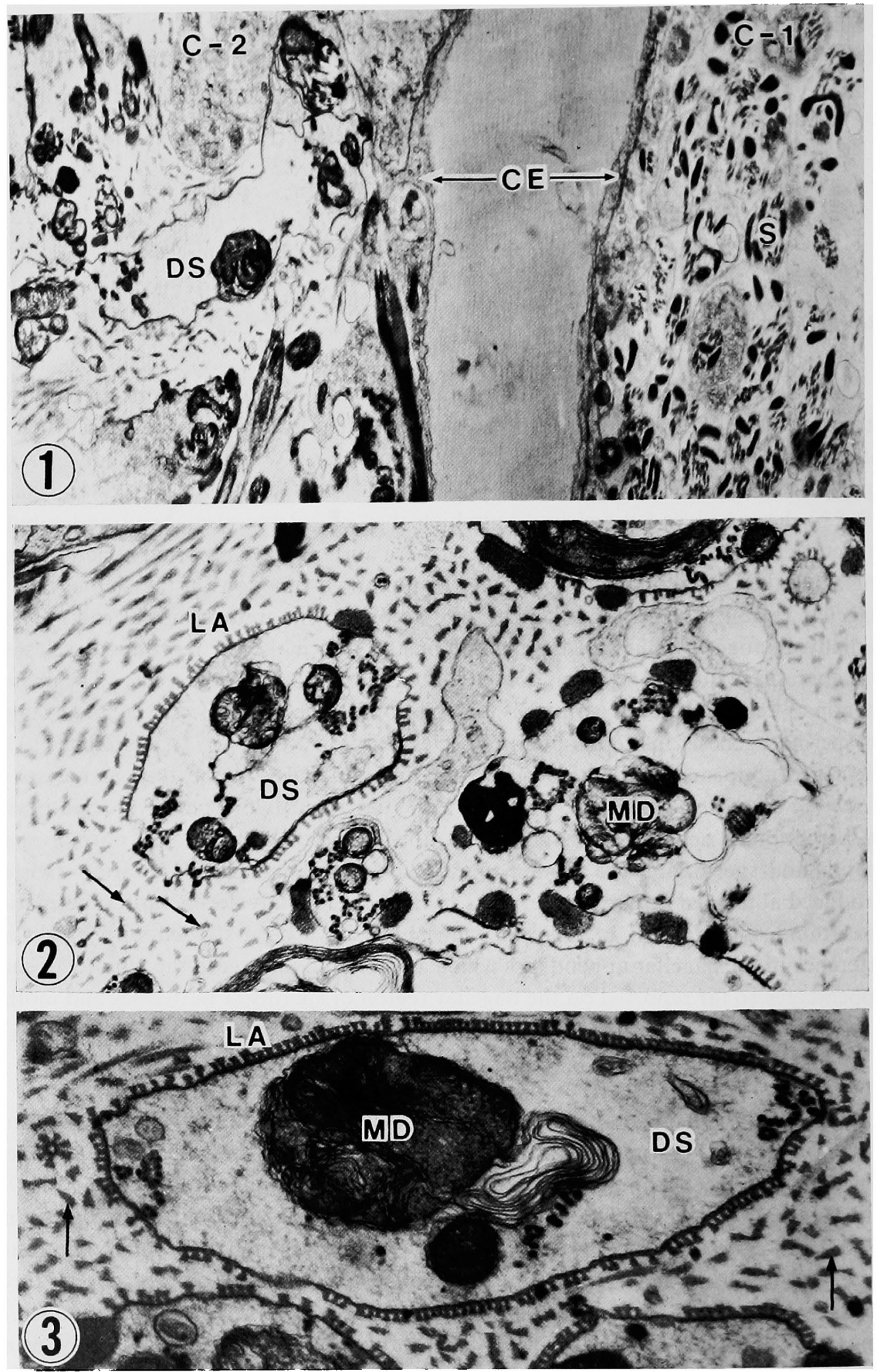
aqueous uranyl acetate followed by lead citrate, and examined in an electron microscope (Hitachi Model HU-12).

\section{Results}

Some of the cysts in the testes of tea-tortrix moth, Homona magnanima were observed to have degenerating spermatids without clear cytoplasmic inclusions except the disorganised nebenkern derivatives (Figs. 1, 2, 3).

Many of these degenerating spermatids were decorated by a variable number of projections having highly organised cross-banded structure with alternating light and dense lines (Fig. 4, inset). Their general structure resembled the laminated appendages reported on the plasma membrane of the Lepidopteran spermatozoa. However, they appeared to far exceed in number when compared to such flagellar appendages in other species of moths and butterflies.

Some of the flagellar appendages were found to be detached from the plasma membrane. Figs. 2, 3 and 4 show some of the detached appendages in the cyst fluid surrounding the developing germ cells.

\section{Discussion}

Some of the testicular cysts of newly emerged tea-tortrix moth contained degenerating spermatids, which appeared to be of bigger size, without clear cellular inclusions. The chromatin seemed to have fragmented and lost, so the giant carrier cell seemed to be apyrene. Gatenby (1917) concluded that "apyrene" chromosomes lacked the energy to coalesce to form the nucleus. Knaben (1931) described normal and abnormal spermatids occurring simultaneously within a single testicular cyst of butterfly, Tischeria angusticolella. Ammann (1954) described the degeneration of germ cells at all stages of spermatogenesis in Lepidopteran species. Meves (1903) described dimorphism in a number of species of Lepidoptera. He called the abnormal spermatozoa "apyrene spermien" and normal "eupyrene spermien" and concluded that the sperm bundles of "apyrene" were several times shorter than normal "eupyrene".

The degeneration of spermatids cannot be due to the want of nourishment as many cysts contained normal spermatids all around a degenerating cyst. However, it is possible that diversion of nourishment to other sources may have caused it, or the degenerating cells may be the source of nutrition for normal sperms. Future work on degeneration of sperm cells can settle many important questions related with this phenomenon.

Figs. 1-3. 1, low magnification view of the two adjoining cysts $(C-1, C-2)$, showing spermatids inside the cyst envelopes (CE). Cyst-1 (C-1) contains normal spermatids (s) while cysts-2 (C-2) contains degenerating spermatids (DS). $\times 11,500.2$, high magnification view of degenerating spermatids (DS) showing the presence of laminated appendages (LA) around them. Many of these appendages have been detached from the plasma membrane (arrows). Some of the disorganised cytoplasmic inclusion can be seen inside the cells. Mitochondrial derivatives (MD). $\times 20,500$. 3, high magnification view of a single degenerating spermatid (DS) decorated with laminated appendages (LA). Appendages detached from the cell membrane can be seen in the cyst fluid

(arrows). Mitochondrial derivatives (MD). $\quad \times 30,000$. 





According to Bowen (1922) the degeneration phenomena in Lepidopteran testes seem to offer many problems which call for an intensive study of the whole germcell cycle for their adequate solution. Roosen-Runge (1977) compares the phenomenon of cell loss with "quality control" measures which serve to select and remove gametes which are in multiple ways not suitable for propagation. According to him the phenomenon of cell loss is highly significant and deserves much more attention than it has received heretofore.

Another outstanding feature of degenerating spermatids is the presence of many appendages around their plasma membranes. These laminated appendages projecting radially can form an interesting study for the future work as their chemical nature and significance is still not known. Structurally they resemble the appendages described for various Lepidopteran sperms, however, their number on the degenerating spermatids of tea-tortrix moth seems to far exceed the number of such appendages so far described in the flagellar region of Lepidopteran sperms. According to Phillips (1970) they arise radially from the plasma membrane like blades on a paddle wheel and extend from anterior tip posteriorly along most of the length of Lepidopteran sperms while they are inside the cysts. He assumes that the flagellar appendages arise from the cell surface.

\section{Summary}

Some of the testicular cysts of one-day-old tea-tortrix moth, Homona magnanima Diakonoff were observed to contain degenerating spermatids which projected variable number of appendages in the flagellar region. These appendages are structurally similar to appendages on the flagellar region of Lepidopteran sperms, but seem to far exceed in number. The significance of these appendages is obscure and needs further work to understand their chemical nature and function.

\section{Acknowledgement}

The author wishes to express his appreciation to Professor, Toshio Nagano, Department of Anatomy, School of Medicine, Chiba University, Japan, for his keen interest during the course of this study. These studies were supported by grants from the Ministry of Education, Science and Culture, Japan.

\section{References}

Ammann, H. 1954. Die postembryonale Entwicklung der weiblichen Geschlechtsorgane in der Raupe von Solenobia triquetrella F. R. (Lepid) mit ergänzenden Bemerkungen über die Entwicklung des männlichen Geschlechtsapparates. Zool. Jahrb. Anat. 73: 337-394.

André, J. 1959. Étude au microscope électronique de l'évolution du chondriome pendant la spermatogénèse du papillon du chou, Pieris brassicae. Ann. Sci. Nat. Zool. Biol. Animale 1: 283-305.

Fig. 4. High magnification view of the laminated appendages (LA) around the degenerating sperm tails. The appendages have cross-banded structure with alternating light and dense lines. Mitochondrial derivatives $(\mathrm{MD}), \times 23,000$. Inset. Magnified portion of the area marked by the arrow showing the laminated structure of the appendages. $\times 45,000$. 
- 1961. Sur quelques détails nouvellement connus de l'ultrastructure des organites vibratiles. J. Ultrastruct. Res. 5: 86-108.

Bowen, R.H. 1922. Studies on insect spermatogenesis V. On the formation of the sperm in Lepidoptera. Quart. J. Micr. Sci. 66: 595-626.

Gatenby, J. B. 1917. The cytoplasmic inclusions of the germ-cells. Part I. Lepidoptera. Quart. J. Micr. Sci. 62: 407-463.

Knaben, N. 1931. Spermatogenese bei Tischeria angusticolella. Dup. Z. Zellforsch. Mikrosk. Anat. 13: 291-323.

Meves, F. 1903. Über oligopyrene und apyrene Spermien und über ihre Entstehung nach Beobachtungen an Paludina und Pygaera. Arch. f. mikr. Anat. 61: 1-84.

Phillips, D. M. 1970. Insect sperm: Their structure and morphogenesis. J. Cell. Biol. 44 (2): 243-277.

Roosen-Runge, E. C. 1977. The Process of Spermatogenesis in Animals. Cambridge. Univ. Press.

Smith, D. S. 1968. Insect Cells: Their Structure and Function. Oliver and Boyd Ltd. Edinburgh, $372 \mathrm{p}$.

Yasuzumi, G. and Oura, C. 1964 a. Spermatogenesis in animals as revealed by electron microscopy XIII. Formation of a tubular structure and two bands in the developing spermatid of the silkworm, Bombyx mori Linne. Z. Zellforsch. 64: 210-226.

- 1964 b. Differential analysis by various fixation techniques of structures present in the developing spermatids of the silkworm. Nature (Lond.) 204: 1197-1198.

- 1965 a. Spermatogenesis in animals as revealed by electron microscipy XIV. The fine structure of the clear band and tubular structure in late stages of development of spermatids of the silkworm, Bombyx mori Linne. Z. Zellforsch. 66: 182-196.

- 1965 b. Spermatogenesis in animals as revealed by electron microscopy XV. The fine structure of the middle piece in the developing spermatids of the silkworm, Bombyx mori Linne. $\mathrm{Z}$. Zellforsch. 67: 502-520. 